\title{
Criminal policy of Russia during a pandemic
}

\author{
Aleksandr Viktorovich Pobedkin ${ }^{1 *}$, Andrey Petrovich Fil'chenko ${ }^{1}$, Tatyana Valentinovna \\ Pinkevich $^{1}$, Natalia Eduardovna Martynenko ${ }^{1}$, and Vladimir Yurievich Zhandrov ${ }^{2}$ \\ ${ }^{1}$ Federal State Public Educational Establishment of Higher Education "Management Academy of the \\ Ministry of the Interior of the Russian Federation", Criminal Policy Department, Moscow, Russia \\ ${ }^{2}$ Federal state educational institution of higher education "Moscow University of the Ministry of \\ internal Affairs of the Russian Federation named after V.Ya. Kikotya", Operational Investigative \\ Activities and Special Equipment Department, Moscow, Russia
}

\begin{abstract}
The consequence of the pandemic caused by COVID-19 was the introduction of social restrictions, which led to an increase in the number of users of social networks, as well as their activity on the Internet. The involvement of citizens in the digital environment has changed the targets of criminal efforts of the criminals. The public's fear of the coronavirus was subjected to criminal exploitation, new forms and methods of theft appeared, as a result, the spectrum of crime shifted to the criminal use of information and communication technologies (hereinafter - ICT. The purpose of the study is to analyze the dynamics of the indicators of Russian crime during the pandemic, to assess the adopted criminal-political decisions in terms of adequacy to the changes in crime, to develop on this basis the proposals for criminal law improvement able to increase the consistency of the current Criminal Code of the Russian Federation and its compliance with the requirements of the criminal-political situation in Russia. The assessment of the sectoral structure consistency in the regulation of criminal liability for committing crimes in the special conditions of a pandemic was used as the main research method. The research was carried out by the authors based on the dialectical method, which made it possible to manage changes in social reality by means of legal response, other scientific methods: sociological, modeling, concrete historical, comparative were applied as well. The results obtained showed that overcoming the negative changes in crime requires adjusting the vector of criminal policy from liberalization towards tightening in relation to crimes committed using ICT. It is proposed to expand the list of aggravating circumstances, limit the use of some mechanisms for terminating criminal liability associated with exemption from it, and review the possibilities of applying conditional conviction to persons who have committed crimes in a pandemic, up to and including refusal of this form of implementation of criminal liability. The formulated new proposals for improving the General Part of the Criminal Code of the Russian Federation restore the consistency of the criminal law and increase the consistency of criminal-political decisions during a pandemic.
\end{abstract}

Keywords: crime prevention, criminal law, penal sanctions

\footnotetext{
* Corresponding author: apodedkin71@ mail.ru
} 


\section{Introduction}

\subsection{Research background}

The spread of COVID-19, which caused the pandemic, has entailed significant changes in the social and economic conditions of Russian society. As a result of the introduction of restrictive measures aimed at curbing the further deterioration of the sanitary and epidemiological situation, a significant number of citizens changed their way of life. Among other circumstances, the factors of growth in the number of users of social networks, as well as their activity on the Internet, have acquired the greatest criminological significance. The increase in the amount of free time in conditions of forced isolation and the desire of citizens to work remotely have made this situation attractive to the criminals who have begun to exploit the public's fear of the coronavirus. The crime rates have changed.

The growth in the number of criminal acts using IT technologies committed during nine months of 2020 increased by $77 \%$ compared to the same period of the previous year. Four of these crimes out of five $(81.5 \%)$ were committed by theft or fraud, and their increase amounted to $83.5 \%$ compared to 2019 . Almost every twelfth $(8.1 \%)$ crime was committed with the aim of illegal production, sale or transfer of narcotic drugs -29.6 thousand facts in absolute terms, in dynamics - and an increase of $65.5 \%$ was observed. New forms of criminal behavior have emerged: sending phishing scam letters to victims on behalf of the World Health Organization, organizing false donations, offering fake compensation for damage from the virus, selling fake drugs, offering dubious medical advice, carrying out hacker attacks on clinics and research laboratories.

\subsection{Theoretical background}

The consequences of the impact of the COVID-19 pandemic on the crime rate are being studied increasingly all over the world. General data were analyzed by Brantingham [1]. At the same time, the results of various studies turned out to be ambiguous. The results of a study carried out by Halford et al. [2] showed a $41 \%$ decline in all reported crimes in selected areas of the UK. Data from Shayegh and Malpede [3] showed an overall drop in crime of $43 \%$ in San Francisco and around 50\% in Oakland. Swedish scientists Gerell, Kardell, and Kindgren [4] also found an overall decrease in reported crimes of 8.8\%. Ashby [5] and Felson, Jiang, and $\mathrm{Xu}$ [6] have indicated a reduction in a common burglary. Australian researchers Payne and Morgan [7] stated that there were no changes in the rates of assault (including sexual) and domestic violence.

On the contrary, an increase in certain types of crime was observed. Data provided by Pietrawska, Aurand and Palmer [8] showed a 64\% increase in a burglary from retailers. The negative consequences of social distancing and isolation and their impact on crime were noted by Bump, Mohler, et al., Usher et al., and Bradbury-Jones and Isham [1, 9-11]. The impact of voluntary home isolation on Internet activity and related crime was noted by Stickle and Felson [12]. Miller and Blumstein [13] pointed out the increase in the victimization of self-isolated citizens from online fraud.

The available theoretical base does not give any correct idea of the changes in crime rates in Russia.

\subsection{Novelty}

The tendencies of Russian crime identified by the authors during the pandemic, expressed in a shift in the spectrum of crimes committed into the field of IT technologies and remote theft 
are new. The formulated proposals for improving the General Part of the Criminal Code of the Russian Federation restore the consistency of the criminal law and increase the consistency of criminal-political decisions during a pandemic.

\subsection{Research hypothesis}

During a pandemic and the social constraints caused by its spread, the structure of crime is changing significantly, which requires a revision of liberal trends in criminal policy regarding criminal liability for crimes committed using ICT.

The purpose of the study is to develop proposals for improving the criminal law instruments that can increase the effectiveness of criminal policy to restrict the negative trends that have manifested themselves in terms of pandemic restrictions.

The objectives of the study are: a) to track the change in the indicators of Russian crime during the COVID-19 pandemic; b) to evaluate the criminal-political decisions adopted in the country from the standpoint of adequacy to the changes in crime, c) to develop proposals for amending and supplementing the criminal law that can increase the consistency of the current Criminal Code of the Russian Federation and its compliance with the requirements of the criminal-political situation in Russia.

\section{$2 \quad$ Methods}

Historical method and method for assessing the consistency of sectoral construction in the regulation of criminal liability for committing crimes in "special conditions". The state has historically recognized an increased social danger for crimes committed during wartime, in a state of emergency, natural or other public disasters.

Nowadays, the commission of any crime in the conditions of (1) an armed conflict or military action, (2) a state of emergency, natural or other public disasters, (3) during mass riots is recognized as an aggravating circumstance for criminal punishment (Clause "l" of Art. 63 of the Criminal Code of the Russian Federation). As for the Special Part of the Criminal Code of the Russian Federation, the aggravation of criminal liability is associated with the commission of a crime in wartime or in a combat situation (Part 3 of Article 331 of the Criminal Code of the Russian Federation), in an environmental emergency (Part 2 of Article 247 of the Criminal Code of the Russian Federation, Part 2 of Article 250, Part 2 of Article 254, paragraph "g" of Part 1 of Article 256 and paragraph "g" of Part 1 of Article 258 of the Criminal Code of the Russian Federation).

\section{$3 \quad$ Results}

In the context of legal restrictions caused by the need to overcome the pandemic, the vector of Russia's criminal policy should be adjusted from liberalization to tightening. The following specific steps are required:

1. Expansion of the list of aggravating circumstances. It is advisable to consider the commission of a crime using ICT in a high alert regime established by the legislation on the protection of the population and territories from natural and man-made emergencies as an aggravating circumstance. This will take into account the increased public danger of committing a crime in a pandemic and will limit judicial possibilities to change the category of the crime committed to a less serious one.

2. Limiting the application of certain mechanisms related to the exemption from criminal liability. For perpetrators who have committed crimes using ICT in a high alert regime, the 
use of such grounds for exemption from criminal liability as active repentance, reconciliation with the victim and the imposition of a court fine should be excluded.

3. Reconsideration of the possibilities of applying conditional conviction to persons who have committed crimes in terms of a pandemic, up to and including the abandonment of this form of implementation of criminal liability.

\section{Discussion}

The formulated proposals relate to the General Part of the Criminal Code of the Russian Federation and follow the trend of tightening criminal policy, which has already manifested itself within the framework of the Special Part of the Criminal Code of the Russian Federation. In 2020, the criminalization affected:

a) the threat of the onset of grave consequences in case of violation of the sanitary and epidemiological rules. The sanction was toughened and a new aggravating qualifying criterion was introduced in the new edition of Art. 236 of the Criminal Code of the Russian Federation;

b) public dissemination of knowingly false information about circumstances posing a threat to the life and safety of citizens (Article 207.1 of the Criminal Code of the Russian Federation) and public dissemination of knowingly false socially significant information, which entailed grave consequences (Article 207.2 of the Criminal Code of the Russian Federation);

c) circulation of counterfeit, substandard and unregistered medicines, medical devices, as well as circulation of counterfeit dietary supplements using the media or information and telecommunication networks, including the Internet (part 1.1 of Article 238.1 of the Criminal Code of the Russian Federation). These solutions are in line with the global trend. Many countries have already adopted measures to regulate liability for the dissemination of damaging false information. Preventive strategies that can be used to mitigate the spread of fake news are also being explored, as reflected in the work of Gradon [14], although these should be critically assessed.

The amendments made to the criminal law indicate a course towards toughening criminal liability during the period of restrictions caused by the pandemic, which should be recognized as justified.

A review of the results of criminalization showed that political decisions were made within the framework of specific manifestations of criminal activity and did not relate to the provisions of the general part of the criminal law. In this regard, the proposals formulated by the authors continue the trend of tightening criminal policy in the context of a pandemic, filling the gap in the General Part of the Criminal Law.

\section{Conclusion}

The study has revealed a significant impact of social constraints caused by the pandemic on both quantitative and qualitative characteristics of crime. Negative tendencies manifested themselves in the form of a shift in the criminal spectrum towards the illegal use of ICT. The existing instruments of the criminal law, which work effectively under normal conditions, have proved to be unsuitable for controlling the spread of crime under conditions of restrictive measures. In this regard, the established trends in the liberalization of criminal policy should be revised taking into account the changes that have occurred in the negative changes in crime during the pandemic. The tightening of criminal policies should not be general in nature, but aimed at deterring ICT-related crime. 


\section{References}

1. G. Mohler, A.L. Bertozzi, J. Carter, M.B. Short, D. Sledge, G.E. Tita, C.D. Uchida, P.J. Brantingham, J. Crim. Justice 68(6973), art. 101692 (2020). https://doi.org/10.1016/j.jcrimjus.2020.101692

2. E. Halford, A. Dixon, G. Farrell, N. Malleson, N. Tilley, Crime Sc. 9, 11 (2020). https://doi.org/10.1186/s40163-020-00121-w

3. S. Shayegh, M. Malpede, SSRN (2020). https://dx.doi.org/10.2139/ssrn.3567394

4. M. Gerell, J. Kardell, J. Kindgren, SocArXiv (2020). https://doi.org/10.31235/osf.io/w7gka

5. M.P.J. Ashby, Crime Sci. 9, 6 (2020). https://doi.org/10.1186/s40163-020-00117-6.

6. M. Felson, S. Jiang, Y. Xu, Crime Sci. 9, 10 (2020). https://doi.org/10.1186/s40163020-00120-X

7. J. Payne, A. Morgan, SocArXiv (2020). https://doi.org/10.31219/osf.io/de9nc

8. B. Pietrawska, S.K. Aurand, W. Palmer, CAP Index, 19.2 (2020)

9. P. Bump, Crime fell in a locked-down New York City - but less than you might think (2020). Accessed on: March 21, 2021. [Online]. Available:

http://www.washingtonpost.com/politics/2020/04/15/crime -fell-locked-down-newyork-city-but-less-than-you-might -think

10. K. Usher, N. Bhullar, J. Durkin, N. Guamfi, D. Jackson, Int J Ment Health Nurs. 29(4), 549-552 (2020). https://doi.org/10.1111/inm.12735

11. C. Bradbury-Jones, L. Isham, J. Clin. Nurs. 29(13-14), 2047-2049 (2020). https://doi.org/10.1111/jocn. 15296

12. B. Stickle, M. Felson, Am. J. Crim. Just. 45, 525-536 (2020). https://doi.org/10.1007/s12103-020-09546-0

13. J.M. Miller, A. Blumstein, Am. J. Crim. Just. 45(2), 515-524 (2020). https://doi.org/10.1007/s12103-020-09555-Z

14. K. Gradon, Soc. Reg. 4(2), 133-148 (2020). https://doi.org/10.14746/sr.2020.4.2.10 